\title{
Comparison of prediction models for two different peripheral stem cell collection protocols in autologous patients: How to avoid errors in calculating total blood volume to process?
}

\author{
Roman Małachowski ${ }^{1, *}$, Olga Grzybowska-Izydorczyk ${ }^{1,2}$, Anna Szmigielska-Kapłon ${ }^{1,2}$, \\ Kamil Brzozowski ${ }^{1}$, Mateusz Nowicki ${ }^{1}$, Kamil Zieliński ${ }^{1}$, Agnieszka Pluta ${ }^{1,2}$, \\ Magdalena Czemerska ${ }^{1,2}$, Piotr Stelmach ${ }^{1,2}$, Agnieszka Wierzbowska ${ }^{1,2}$ \\ ${ }^{1}$ Copernicus Memorial Hospital in Łódź, Comprehensive Center and Traumatology, Łódź, Poland \\ ${ }^{2}$ Medical University of Łódź, Łódź, Poland
}

\section{Abstract}

Introduction: Calculating accurate blood volume to process is a critical practice in apheresis planning; therefore, researchers try to develop dedicated prediction models. In this analysis, we have attempted to compare three algorithms for two different apheresis collection protocols.

Methods: In a retrospective study, we have analyzed 137 apheresis procedures performed on 100 autologous patients. Apheresis procedures were performed with the Spectra Optia apheresis device with two protocols: mononuclear cell collection (MNC) and continuous mononuclear cell collection (CMNC). Three algorithms: a model based on mean collection efficiency (CE2), a linear regression model, and a power regression model were validated by plotting collected $\mathrm{CD} 34^{+}$cell dose versus predicted CD34 ${ }^{+}$cell dose.

Results: All models showed high predictability for MNC procedure, a high correlation of predicted CD34 ${ }^{+}$yield and actual CD34 $4^{+}$yield $\left(R^{2}=0.9547 ; 0.9487 ; 0.9474\right.$ for CE2-based model, linear and power regression model, respectively). In contrast, alteration between models for the cMNC procedure was greater $\left(R^{2}=0.8049,0.7970\right.$, and 0.8169$)$ with a higher number of overpredictions. Further analysis revealed that for low $\mathrm{CD} 34^{+}$precounts blood volume to process, calculated with the three models, differ significantly up to fivefold times.

Conclusions: Utilizing regression models may lead to calculation errors, which can affect undercollection, repetition of apheresis, or even mobilization failure. Contrary to regression models, the model based on mean CE2 gave the most accurate prediction both for MNC and CMNC procedures. Although new prediction algorithms are created, this simple formula remains a reliable tool that promotes careful planning of apheresis, thus improving patient safety.

Key words: algorithm, apheresis, CMNC, MNC, Optia, peripheral blood stem cells

Acta Haematologica Polonica 2021; 52, 1: 38-47

\section{Introduction}

Understanding the principles of the apheresis technique is crucial for performing an efficient and safe peripheral blood stem cell (PBSC) collection. Optimizing all steps of the mobilization process, that is, preparation of patient, timing of the collection, and collection itself has been of interest to all haematology professionals involved in
*Address for correspondence: Roman Małachowski, Copernicus

Memorial Hospital in Łódź, Comprehensive Center and Traumatology, Pabianicka 62, 93-513 Łódź, Poland, e-mail: roman.malachowski@10g.pl
PTHiT

Copyright (c) 2021

The Polish Society of Haematologists and Transfusiologists,

Insitute of Haematology and Transfusion Medicine.

All rights reserved. 
hemopoietic stem cell transplantation (HSCT). PBSC collection aims to gather a sufficient number of cells for HSCT with minimizing the risk of adverse events associated with the procedure. It indicates performing apheresis at the right time with the application of a minimal number of procedures [1]. The kinetics of $\mathrm{CD} 34^{+}$cell increase in patients mobilized with granulocyte colony-stimulating factor (G-CSF), combined with chemotherapy, is difficult to predict. Numerous investigators focus on the timing of apheresis, that is, initiation of the procedure. It is widely approved to start apheresis with $\mathrm{CD} 34^{+}$cells circulating in blood at a minimal level of 10-20 cells in microliter [2-5]. A very strong correlation between CD34 precount and yield (CD34 ${ }^{+}$cells/kg of body weight) enables to determine a minimal $\mathrm{CD} 34^{+}$precount required for the collection of a minimal target dose and, in consequence, decreasing the number of unnecessary procedures [6-8]. This scheme, however, in which a fixed blood volume is processed through a separator, seems to be insufficient considering the difference in the patient's height and body weight.

A need for an individualized approach to a patient led to a development of different algorithms, which determine blood volume to process through a blood separator to reach a particular $\mathrm{CD} 4^{+}$cell target. Calculations based on the mean collection efficiency (CE2) (with an assumption that the $\mathrm{CD}_{34}{ }^{+}$cell level in blood is equal throughout the whole procedure) provided a simple and fast method for calculating blood volume required to be processed [9-13]. This method enables to reduce citrate toxicity, improves quality control, and promotes best practices by enabling benchmarking [12]. Furthermore, this algorithm was modified by decreasing the calculated CE to decrease the number of underestimated procedures, which could result in mobilization failure [14, 15].

An alternative method, first introduced by Mitterer et al. in the mid-1990s, applies a linear regression model [16].

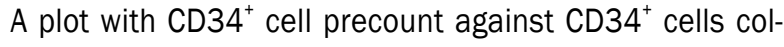
lected per $10 \mathrm{~L}$ whole blood volume processed is used for creating equations to determine blood volume to process and predicted $\mathrm{CD} 34^{+}$yield $[17,18]$.

To increase accuracy, these models can be applied for stratified groups, that is, healthy donors, patients with different diagnoses [18]. Furthermore, the regression model could be tested for a nonlinear correlation. It leads to creating many models, but a question arises which model should be chosen? In this article, we try to compare the utility of these models and assess their accuracy. Additionally, to enlarge the extent of research, we build each model for two different PBSC collection protocols. We also observe the efficacy of the mononuclear cell collection (MNC) protocol and continuous mononuclear cell collection (cMNC) protocol.

\section{Methods}

\section{Patients and apheresis}

A retrospective study was performed on 100 consecutive patients, 137 peripheral blood stem cell collections, completed in a single center between May 2015 and November 2017. Information was collected on patient age, sex, diagnosis, weight, height, peripheral $\mathrm{CD} 34^{+}$precount before the procedure $\left(\mathrm{CD} 34^{+} \mathrm{pre}\right)$, total blood volume (TBV) processed and yield - number of CD $34^{+}$cells collected per $\mathrm{kg}$ of recipient body weight (CD34 ${ }^{+} / \mathrm{kg}$ body weight). Patient data are summarized in Table I.

All procedures were performed with Spectra Optia apheresis device with two protocols: MNC $(n=77)$ and cMNC ( $n=60)$; the latter was introduced in 2014. Peripheral venous access was used whenever the nursing staff was able to insert cannulas (18 G-16 G) palpably; otherwise, a central venous catheter $(13 \mathrm{~F})$ was inserted before apheresis. A median inlet flow rate of $39 \mathrm{~mL} / \mathrm{min}$ (range, 27-53 $\mathrm{mL} / \mathrm{min}$ ) was used for MNC and $50 \mathrm{~mL}$ / /min (range, 27-77 mL/min) was used for cMNC. An initial 12:1 inlet:anticoagulant (AC) ratio was used for both protocols. It was necessary to decrease the ratio in a few MNC procedures where clothing in collection line was observed.

The CD34 target dose was $8 \times 10^{6}$ cells $/ \mathrm{kg}$ of body weight for multiple myeloma patients and $4 \times 10^{6} \mathrm{cells} / \mathrm{kg}$ of body weight for lymphoma patients. Total blood volume to the process was roughly estimated by the operator based on previous experiences.

Collection efficiency (CE2) was calculated only with the pre-apheresis $\mathrm{CD} 34^{+}$count. The mean CE2 value was used for formulating a collection efficiency-based prediction model.

$$
\begin{aligned}
& C E 2=\frac{C D 34^{+} / \mu L \text { prod } \times \text { vol }}{C D 34^{+} / \mu L \text { pre } \times \text { TBV processed }} \\
& C E 1=\frac{C D 34^{+} / \mu L \text { prod } \times \text { vol }}{\frac{C D 34^{+} / \mu L \text { pre }+C D 34^{+} / \mu L \text { post }}{2} \times T B V \text { processed }}
\end{aligned}
$$

\section{Prediction models and validation}

The purpose of each model is to determine blood volume to process knowing the CD34 ${ }^{+}$pre. To validate their accuracy, created formulas were used for calculation of the predicted $\mathrm{CD}_{4} 4^{+}$yield based on the actual blood volume processed (TBV processed). The predicted CD34 ${ }^{+}$yield was compared to the actual $\mathrm{CD} 34^{+}$yield. Trend lines were set to cross point 0; 0 to eliminate an error where the points lie close to the trend line but are located in the underprediction or overprediction area of the validation graph.

\section{Model based on the mean collection efficiency (CE2)}

Blood volume to process can be calculated by equation: 
Table I. Patient characteristics

\begin{tabular}{|c|c|c|}
\hline Variable & MNC & cMNC \\
\hline Number of patients & $n=50$ & $n=50$ \\
\hline Sex (male, female) & 30,20 & 32,18 \\
\hline $\begin{array}{l}\text { Age, median } \\
\text { (range) }\end{array}$ & $\begin{array}{c}61 \\
(23-69)\end{array}$ & $\begin{array}{c}60 \\
(26-70)\end{array}$ \\
\hline $\begin{array}{l}\text { Donor body weight [kg], } \\
\text { median (range) }\end{array}$ & $\begin{array}{c}70 \\
(42-110)\end{array}$ & $\begin{array}{c}74 \\
(49-114)\end{array}$ \\
\hline Height, median (range) & $\begin{array}{c}168 \\
(148-190)\end{array}$ & $\begin{array}{c}170 \\
(149-190)\end{array}$ \\
\hline $\begin{array}{l}\text { Donor TBV [mL], } \\
\text { median (range) }\end{array}$ & $\begin{array}{c}4555 \\
(3004-6470)\end{array}$ & $\begin{array}{c}4693 \\
(3112-6470)\end{array}$ \\
\hline \multicolumn{3}{|l|}{ Diagnosis } \\
\hline Multiple myeloma & 40 & 36 \\
\hline Hodgkin lymphoma & 1 & 6 \\
\hline Mantle cell lymphoma & 3 & 3 \\
\hline $\begin{array}{l}\text { Diffuse large B-cell } \\
\text { lymphoma }\end{array}$ & 2 & 4 \\
\hline $\begin{array}{l}\text { Peripheral T-cell } \\
\text { lymphoma }\end{array}$ & 1 & 1 \\
\hline Follicular lymphoma & 1 & 0 \\
\hline Burkitt lymphoma & 1 & 0 \\
\hline $\begin{array}{l}\text { Blastic plasmacytoid } \\
\text { dendritic cell neo- } \\
\text { plasm }\end{array}$ & 1 & 0 \\
\hline \multicolumn{3}{|l|}{ Mobilization regimen } \\
\hline Cytarabine + G-CSF & 35 & 36 \\
\hline $\begin{array}{l}\text { Cytarabine + G-CSF } \\
+ \text { plerixafor }\end{array}$ & 2 & 1 \\
\hline $\mathrm{DCEP}+\mathrm{G}-\mathrm{CSF}$ & 4 & 3 \\
\hline R-DHAP + G-CSF & 1 & 2 \\
\hline ICE + G-CSF & 1 & 2 \\
\hline Dexa-BEAM + G-CSF & 1 & 1 \\
\hline $\mathrm{DHAP}+\mathrm{G}-\mathrm{CSF}$ & 2 & 5 \\
\hline $\mathrm{R}-\mathrm{GDP}+\mathrm{G}-\mathrm{CSF}$ & 1 & 0 \\
\hline IGEV + G-CSF & 1 & 0 \\
\hline $\begin{array}{l}\text { DCEP + G-CSF } \\
+ \text { plerixafor }\end{array}$ & 1 & 0 \\
\hline G-CSF + plerixafor & 1 & 0 \\
\hline \multicolumn{3}{|l|}{ Venous access } \\
\hline Peripheral access & 37 & 29 \\
\hline $\begin{array}{l}\text { Central venous } \\
\text { catheter }\end{array}$ & 13 & 21 \\
\hline
\end{tabular}

MNC - mononuclear cell collection; cMNC - continuous mononuclear cell collection; TBV - total blood volume; G-CSF - granulocyte colony-stimulating factor; DCEP - dexamethasone, cyclophosphamide, etoposide, and cisplatin; R-DHAP - dexamethasone, cytarabine, cisplatin, rituximab; ICE - ifosfamide, carboplatin, etoposide; Dexa-BEAM - dexamethasone, carmustine, etoposide, cytarabine, melphalan; DHAP - dexamethasone, cytarabine, cisplatin; R-GDP - rituximab, gemcitabine, cisplatin, dexamethasone, rituximab; IGEV - ifosfamide, gemcitabine, vinorelbine, prednisone blood volume to process $[\mathrm{mL}]=$

$$
=\frac{\text { CD34 } 4^{+} \text {target }\left[\frac{\text { cells }}{\mathrm{kg} \text { body weight }}\right] \times \text { body weight }[\mathrm{kg}]}{C D 34^{+} \text {pre }\left[\frac{\text { cells }}{\mathrm{mL}}\right] \times \mathrm{CE} 2[\%]}
$$

Predicted $\mathrm{CD} 34^{+}$dose [cells/kg body weight] can be calculated by equation:

$$
\begin{aligned}
& C D 34^{+} \text {predicted }\left[\frac{\text { cells }}{\mathrm{kg} \text { body weight }}\right]= \\
& \text { TBV processed }[\mathrm{mL}] \times \mathrm{CD} 34^{+} \text {pre }\left[\frac{\text { cells }}{\mathrm{mL}}\right] \times \text { CE2 [\%] }
\end{aligned}
$$

$$
\text { body weight [kg] }
$$

\section{Regression model}

A plot with $\mathrm{CD} 34^{+}$collected/TBV processed [cells/kg body weight/mL] against CD34 ${ }^{+}$pre enables creation of linear and power estimation curves, which are elucidated with equations $y=a x+b$ and $y=c x^{n}$. This regression model allows for the formation of the following formulas.

Linear regression:

blood volume to process $[\mathrm{mL}]=$

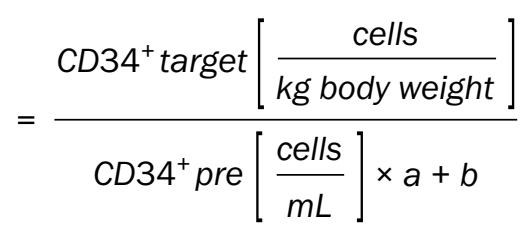

predicted $\mathrm{CD} 34^{+}\left[\frac{\text { cells }}{\mathrm{kg} \text { body weight }}\right]=$

$=T B V$ processed $[\mathrm{mL}] \times\left(\mathrm{CD} 34^{+}\right.$pre $\left.\left[\frac{\text { cells }}{\mathrm{mL}}\right] \times a+b\right)$

Power regression:

blood volume to process $[\mathrm{mL}]=$

$=\frac{C D 34^{+} \text {target [cells } / \mathrm{kg} \text { body weight] }}{c \times\left(C D 34^{+} \text {pre }\left[\frac{\text { cells }}{\mathrm{mL}}\right]\right)^{n}}$

$\mathrm{CD} 34^{+}$predicted $\left[\frac{\text { cells }}{\mathrm{kg} \text { body weight }}\right]=$

$=T B V$ processed $[m L] \times c \times\left(C D 34^{+} \text {pre }\left[\frac{\text { cells }}{m L}\right]\right)^{n}$

CE - collection efficiency; TBV processed - actual blood volume processed during collection; vol. - product volume; $\mathrm{CD} 4^{+} / \mu \mathrm{L}$ pre - patient pre-apheresis $\mathrm{CD} 34^{+}$blood cell count; $\mathrm{CD} 34^{+} / \mu \mathrm{L}$ post - patient post-apheresis $\mathrm{CD} 34^{+}$blood cell count; $\mathrm{CD} 34^{+} / \mu \mathrm{L}$ prod - product $\mathrm{CD} 34^{+}$cell count. 


\section{Statistical analysis}

For patient characteristics and device performance, descriptive statistics was used. Results are presented as median (min, max). The Spearman's rank correlation coefficient was used to determine a relationship between the variables. The Wilcoxon signed-rank test assessed the hemoglobin loss after the procedure. Mann-Whitney U test compared the differences between protocol parameters (STATISTICA, version 13, StatSoft).

\section{Results}

\section{MNC vs. cMNC protocol}

\section{Safety}

The default setting of 12:1 inlet:anticoagulant (AC) ratio and the same blood volume processed expectedly did not contribute to difference in the volume of $\operatorname{ACD}(\mathrm{A})$ infused to patients: MNC $973 \mathrm{~mL}(337,1543)$, cMNC $894 \mathrm{~mL}$ (451, 1600) (Table II). In both procedures, only mild adverse events occurred occasionally, and they were mitigated by oral supplementation and calcium gluconate in saline intravenous drip infusion.

Conversely, a significant difference was observed in platelet loss, higher for the MNC protocol by $24.2 \%$ ( -5.7 to 60.9), lower for the CMNC protocol $12.2 \%$ (-17.3 to 38.3). The platelet CE2 confirms higher platelet attrition for the MNC protocol 21.9\% (9.1-47.5) versus 15.9\% (10.2-21.3) for CMNC. The better performance of the CMNC protocol is a result of lower packing factor (lower $g$ force), implemented in the Spectra Optia centrifuge. Thicker buffy coat in the $\mathrm{CMNC}$ protocol allows for more selective separation in terms of platelet product contamination.

In contrast, the level of hemoglobin in patient does not change for the MNC protocol after the procedure $p=0.47$, but it decreases significantly after the collection procedure performed with the $\mathrm{CMNC}$ disposable set procedure $p=0.009$ (Table III). Again, this is a result of the technical solution implemented in the Spectra Optia centrifuge. The manufacturer recommends in the $\mathrm{CMNC}$ protocol to set the collection preference setting to collect product containing approximately 5\% RBC. The Htc level we reached in our center is $3.0 \%(0.7-5.6)$, which is significantly higher than in the MNC setup (Htc 1.4\% (0.8-3.7)). We indeed collected more RBC in the collection bag with the CMNC protocol $4.94 \mathrm{~mL}$ (1.9-14.03) than with MNC $3.96 \mathrm{~mL}$ (1.40-13.34).

The difference between the procedures is also distinguishable in cell concentration. White blood count (WBC) and granulocyte count in $1 \mu \mathrm{L}$ of product was higher when performed with a new procedure. Despite this fact, the granulocyte percentage and overall number of granulocytes did not differ.

\section{Performance}

The time and effective collection time (average flow rate) differed favorably for the cMNC procedure (Table II). The manufacturer recommends not to exceed the blood flow rate of $62 \mathrm{~mL} / \mathrm{min}$ for the MNC procedure to maintain the desired packing factor in the centrifuge, which elsewise could lead to reduced collection efficiency. The new protocol allows us to perform the procedure at higher inlet flows equally effective. However, with the application of this new procedure, we reached blood inlet flow above $62 \mathrm{~mL} / \mathrm{min}$ only in seven cases, which was caused by vascular access limitations. With peripherally inserted cannulas, it is difficult to exceed the blood flow rate of $60 \mathrm{~mL} / \mathrm{min}$. Moreover, the blood flow rate may be limited by the recommended maximum anticoagulant infusion rate of $1.2 \mathrm{~mL} / \mathrm{min} / \mathrm{kg}$ body weight. The higher effective collection time, obtained with the cMNC procedure, can be explained by lower sensitivity to blood flow changes.

Collection efficiency CE2 calculated with $\mathrm{CD} 34^{+}$precount alone was significantly higher for the MNC protocol. The different efficiency for both protocols is also confirmed by other useful and widely utilized parameters, that is, collection rate (Table II). Although the $\mathrm{CD} 34^{+}$precount did vary between the two cohorts, the performance parameters can be compared between the two groups of patients as long as the processed TBV is similar [19]. In our study, CE2 is independent of CD34 $4^{+}$precount $(p=0.095$ for MNC and $p=0.281$ for $\mathrm{cMNC}$ ), which hereby supports this reasoning.

\section{Regression analysis}

The regression models showed a strong and very strong correlation between $\mathrm{CD} 34^{+}$precount and cells collected per $1 \mathrm{~L}$ of blood volume processed both for MNC and CMNC protocol (Figure 1). This supports the use of $\mathrm{CD}_{3} 4^{+}$precount for the calculation of blood volume to process. For the MNC protocol, the linear and power model did not show differences resulting in similar $R^{2}$. Interestingly, for the cMNC protocol, power regression showed a better correlation $\left(R^{2}=0.9122\right.$ vs. $\left.R^{2}=0.7925\right)$.

\section{Validation}

We observed a high correlation of predicted $\mathrm{CD} 34^{+}$yield and actual $\mathrm{CD}_{3} 4^{+}$yield for the MNC protocol for all three algorithms: based on the mean CE2, linear, and power regression (Figure $2 \mathrm{~A}-\mathrm{C}$ ). $R^{2}$ was equal to $0.9547,0.9487$, and 0.9474 respectively. It confirms high reproducibility and stability of the procedure.

During the CMNC procedure validation, we noticed differences between prediction algorithms. The power regression model and CE2-based one gave similar results regarding $R^{2}=0.8049$ and 0.8169 (Figure 2D, F), respectively, but the relationship between the predicted and collected $\mathrm{CD}_{4} 4^{+}$yield in the linear model contributed to a poorer correlation $\left(R^{2}=0.7970\right.$, Figure $\left.2 \mathrm{E}\right)$. Moreover, a comparison of validation outcomes for MNC and CMNC procedures reveals that overall the accuracy of $\mathrm{CMNC}$ prediction models is lower. The final yield is less predictive suggesting lower stability of the procedure or lesser device automation. 
Table II. Patient pre-apheresis haematology, procedure performance

\begin{tabular}{|c|c|c|c|c|c|}
\hline \multirow[t]{2}{*}{ Variable } & \multicolumn{2}{|r|}{ NMC } & \multicolumn{2}{|r|}{ cMNC } & \multirow[t]{2}{*}{$p$} \\
\hline & $\mathrm{n}$ & Median (range) & $\mathrm{n}$ & Median (range) & \\
\hline \multicolumn{6}{|l|}{ Preapheresis haematology } \\
\hline $\mathrm{CD} 34[/ \mu \mathrm{L}]$ & 77 & $41.0(2.5-1500.0)$ & 60 & $110.5(8.0-1106.0)$ & 0.010 \\
\hline WBC $\left[\times 10^{9} / \mathrm{L}\right]$ & 77 & $20.78(5.05-100.02)$ & 60 & $22.26(4.00-65.12)$ & NS \\
\hline PLT $\left[\times 10^{9} / \mathrm{L}\right]$ & 72 & $75(37-233)$ & 60 & $80(41-282)$ & NS \\
\hline Granulocytes $\left[\times 10^{9} / \mathrm{L}\right]$ & 77 & $16.62(3.27-93.41)$ & 60 & $17.58(2.71-55.00)$ & NS \\
\hline \multicolumn{6}{|l|}{ Safety } \\
\hline PLT loss [\%] & 66 & $24.2(-5.7-60.9)$ & 56 & $12.2(-17.3-38.3)$ & 0.002 \\
\hline PLT CE1 [\%] & 66 & $21.9(9.1-47.5)$ & 56 & $15.9(10.2-21.3)$ & $<0.001$ \\
\hline ACD infused & 65 & $973(377-1543)$ & 59 & $894(451-1600)$ & NS \\
\hline \multicolumn{6}{|l|}{ Procedure } \\
\hline TBV processed & 77 & $2.20(1.10-3.00)$ & 60 & $2.15(1.30-3.20)$ & NS \\
\hline Whole blood processed [mL] & 77 & $10162(4218-16175)$ & 60 & 9806 (4930-17603) & NS \\
\hline Procedure time [min] & 77 & $261(137-366)$ & 60 & $203(115-497)$ & $<0.001$ \\
\hline $\begin{array}{l}\text { effective collection time (average flow rate) } \\
{[\mathrm{mL} / \mathrm{min}]}\end{array}$ & 77 & $39(27-53)$ & 60 & $50(27-77)$ & $<0.001$ \\
\hline \multicolumn{6}{|l|}{ Product } \\
\hline Total collect volume pump [mL] & 77 & $260(100-580)$ & 60 & 177 (104-295) & $<0.001$ \\
\hline $\mathrm{Htc}[\%]$ & 77 & $1.4(0.8-3.7)$ & 60 & $3.0(0.7-5.6)$ & \\
\hline WBC $\left[\times 10^{9} / \mathrm{L}\right]$ & 77 & & 60 & 260.805 (56.580-713.97) & $<0.001$ \\
\hline $\mathrm{PLT}\left[\times 10^{9} / \mathrm{L}\right]$ & 77 & & 60 & $636(255-2426)$ & NS \\
\hline Granulocytes $\left[\times 10^{9} / L\right]$ & 77 & & 60 & 71.790 (11.76-310.97) & $<0.001$ \\
\hline Granulocytes [\%] & 77 & & 60 & $29.523(0.702-75.41)$ & NS \\
\hline Granulocyte content $\left[\times 10^{9}\right]$ & 76 & $12.9(0.3-55.1)$ & 59 & $13.5(0.2-41.7)$ & NS \\
\hline MNC prod $\left[\times 10^{9} / \mathrm{L}\right]$ & 77 & 98.44 (31.470-166.27) & 60 & $133.655(23.540-341.74)$ & $<0.001$ \\
\hline MNC [\%] & 77 & $50.77(24.26-94.66)$ & 60 & $50.44(14.07-87.88)$ & NS \\
\hline Neutrophils $\left[\times 10^{9} / \mathrm{L}\right]$ & 77 & $46.88(2.000-152.80)$ & 60 & 63.905 (11.76-274.54) & $<0.001$ \\
\hline Recipient CD34 ${ }^{+} / \mathrm{kg}$ & 77 & $3.10(0.31-61.90$ & 60 & $7.06(0.40-48.30)$ & 0.027 \\
\hline $\mathrm{CD} 34+$ total $\left[\times 10^{9}\right]$ & 77 & $201.24(21.94-5320.08)$ & 60 & $567.94(35.84-4103.72)$ & 0.023 \\
\hline CD34+ [cells $/ \mu \mathrm{L}]$ & 77 & $1133.0(93.8-22167.0)$ & 60 & 2961.5 (128.0-22063.0) & $<0.001$ \\
\hline RBC content $[\mathrm{mL}]$ & 77 & $3.96(1.40-13.34)$ & 60 & $4.94(1.9-14.03)$ & 0.001 \\
\hline \multicolumn{6}{|l|}{ Performance } \\
\hline CD34 CE2 [\%] & 77 & $58.82(31.55-157.38)$ & 60 & $51.26(11.27-100.20)$ & 0.003 \\
\hline CD34 CE1 [\%] & 0 & - & 31 & 57.36 (28.69-107.58) & - \\
\hline MNC CE1 [\%] & 77 & $81.8(28.1-233.5)$ & 60 & $69.7(9.2-253.4)$ & 0.011 \\
\hline Collection rate $[\mathrm{mL} / \mathrm{kg}]$ & 77 & $71.93(27.47-260.00)$ & 60 & $59.50(23.39-204.55)$ & 0.027 \\
\hline Throughput [Cr/min] & 77 & $0.2790(0.1122-0.9886)$ & 60 & $0.2970(0.0629-0.6796)$ & NS \\
\hline
\end{tabular}

MNC - mononuclear cell collection; CMNC - continuous mononuclear cell collection; WBC - white blood count; NS - not significant; PLT - platelets; TBV - total blood volume; RBC - red blood count; $\mathrm{CE}$ - collection efficiency

If we further analyze the linear regression validation plot for CMNC, we notice that the estimated and real CD34 yields deflect from an ideal trend line toward lower yields. To further investigate models for each protocol, we plotted predicted blood volume to process to target $8 \times 10^{6} \mathrm{CD}_{3} 4^{+} /$ $/ \mathrm{kg}$ body weight, which is the most common case (Figure 3 ). For $\mathrm{CD}_{3} 4^{+}$precount above $100 \mathrm{CD} 34^{+} / \mu \mathrm{L}$, the calculated blood volume to process is comparable for all models. The
Table III. Hemoglobin loss (Wilcoxon signed-rank test)

\begin{tabular}{l|c|c|c|c|} 
Variable & \multicolumn{2}{|c|}{ MNC } & \multicolumn{2}{c}{ cMNC } \\
\cline { 2 - 5 } & $n$ & Median (range) & $n$ & Median (range) \\
\hline Hb pre & 70 & $9.6(8.0-15.1)$ & 55 & $10.0(7.9-13.2)$ \\
Hb post & 70 & $9.6(7.1-14.9)$ & 55 & $9.7(7.6-12.4)$ \\
$p$ & & 0.47 & & 0.009
\end{tabular}

MNC - mononuclear cell collection; $\mathrm{CMNC}$ - continuous mononuclear cell collection; $\mathrm{Hb}$ - hemoglobin 


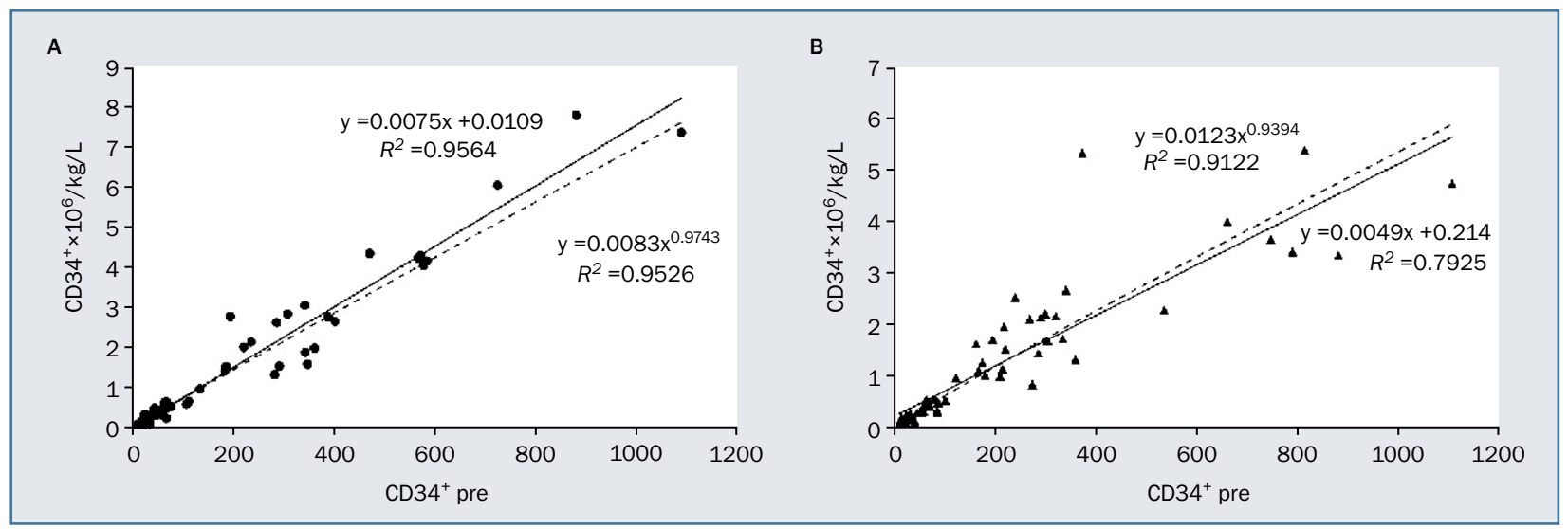

Figure 1. Regression model curves. Solid lines represent the linear model, dotted lines represent power regression model: mononuclear cell collection (MNC) protocol (A) and continuous mononuclear cell collection (cMNC) protocol (B)

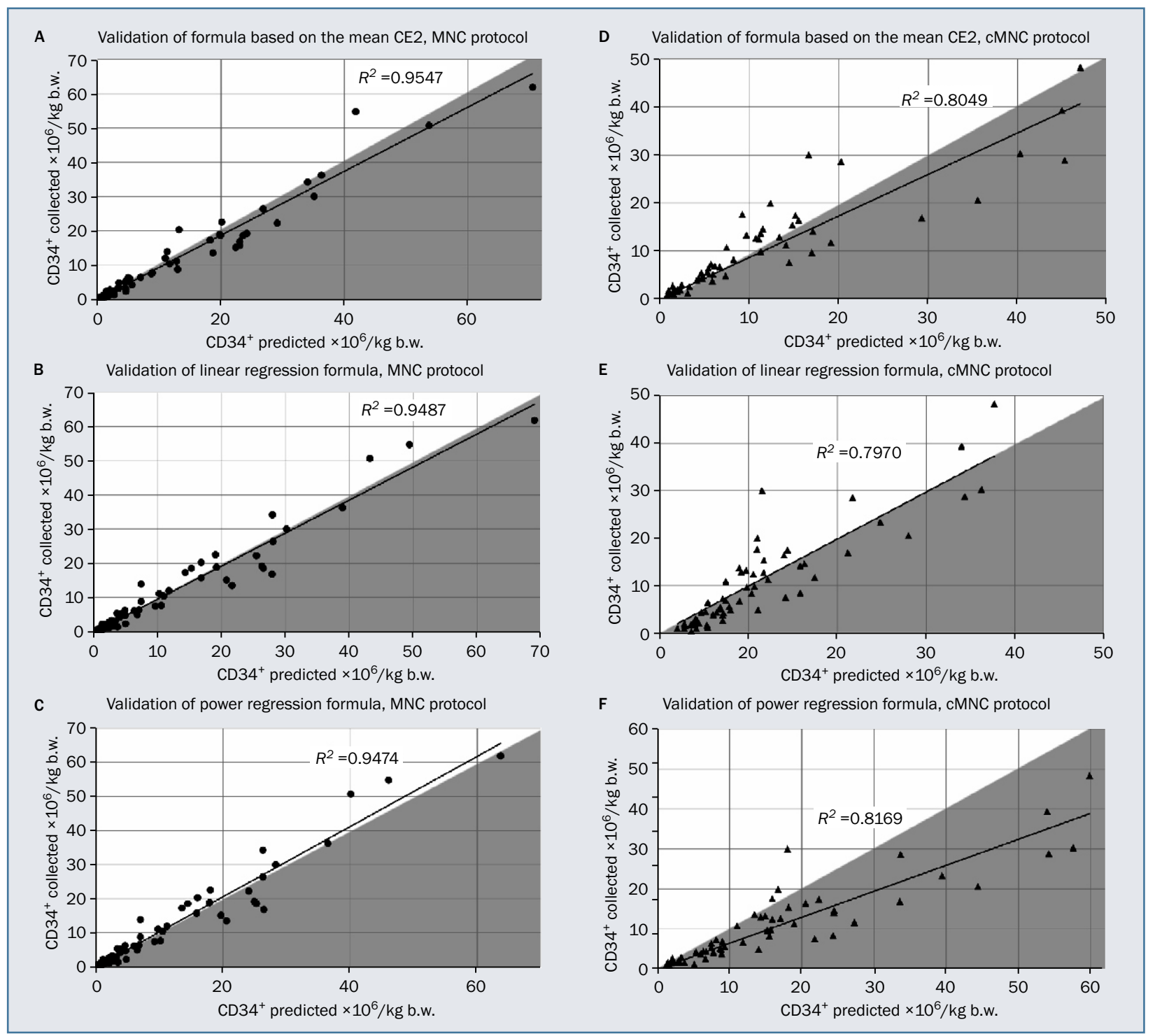

Figure 2A-F. Validation plots for mononuclear cell collection (MNC) and continuous mononuclear cell collection (cMNC) protocols. Collected versus predicted $\mathrm{CD} 34^{+}$dose. The white area of the graph represents undercollection, that is, less $\mathrm{CD}_{3} 4^{+}$cells were collected than the model predicted. The grey area represents overcollection, more $\mathrm{CD} 34^{+}$cells were collected than the model predicted. Overcollection also implicates that the model has underestimated blood volume to process, which would enable to obtain the desired CD34 ${ }^{+}$target dose 
A Blood volume to process, target $\mathrm{CD} 34^{+} 8 \times 10^{6}$ cells/kg b.w., MNC

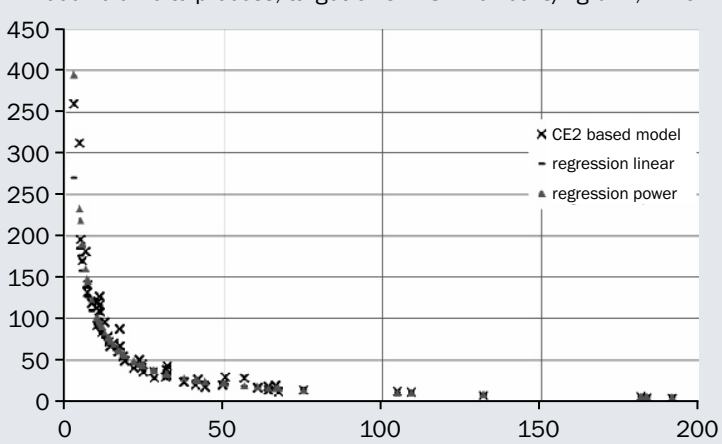

B Blood volume to process [L], target $\mathrm{CD} 34^{+} 8 \times 10^{6} \mathrm{cells} / \mathrm{kg}$ b.w., cMNC

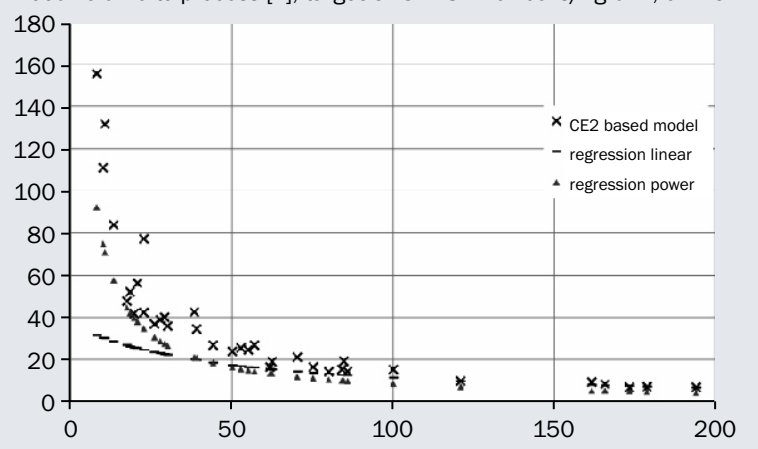

Figure 3A, B. Predicted blood volume to process $[\mathrm{L}]$ versus $\mathrm{CD} 34^{+}$pre. For the continuous mononuclear cell collection (CMNC) protocol, the differences in predicted volume increase significantly with decreasing $\mathrm{CD}_{3} 4^{+}$pre

A

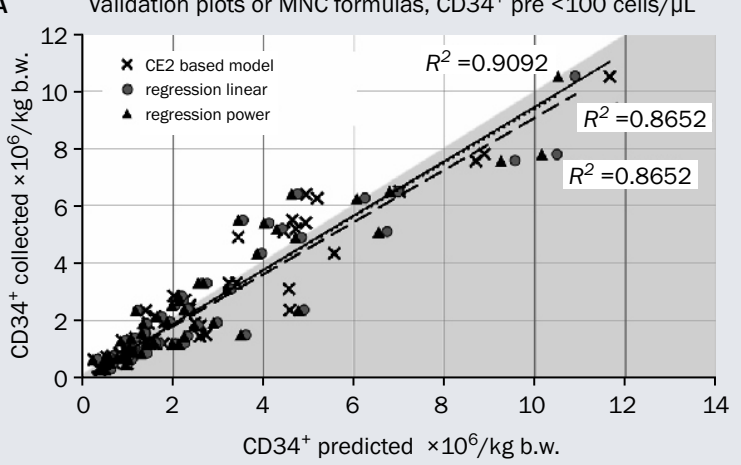

B

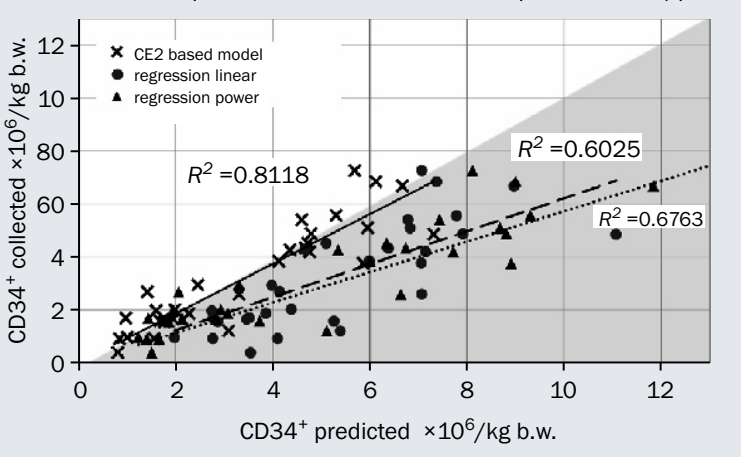

Figure 4A, B. Validation plots for mononuclear cell collection (MNC) and continuous mononuclear cell collection (cMNC) protocols for CD34 ${ }^{+}$ pre $<100$ cells $/ \mu \mathrm{L}$. Collected versus predicted $\mathrm{CD} 34^{+}$dose. The white area of graph represents underprediction, the gray area represents overcollection. Solid, dashed, and dotted trend lines denote CE2-based model, linear regression, and power regression, respectively. MNC models give analogous results. For the CMNC procedure, only the CE2-based model contributes to a good correlation where neither undercollections or overcollections are significantly dominant

difference rises below $100 \mathrm{CD} 34^{+} / \mu \mathrm{L}$, and the difference in the values is from twofold even up to fivefold.

\section{Validation $\mathrm{CD} 34^{+}$precount $<100$ cells $/ \mu \mathrm{L}$}

Again, by generating a validation plot we examined the accuracy of models for collections with $\mathrm{CD} 34^{+}$precount below

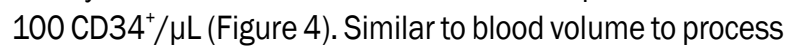
(Figure $3 \mathrm{~A}$ ), models for the MNC procedure, based on the mean CE2, linear, and power regression give comparable results (Figure 4A). A very good correlation, which is almost close to ideal, is observed for trend lines. The coefficient of determination equals $0.9092,0.8652,0.8652$, respectively. For the $\mathrm{CMNC}$ protocol, the three models give different results (Figure 4B). The linear and power regression models show a low correlation, where $R^{2}=0.6025, R^{2}=0.6763$ with most points lying in the overprediction part of the validation graph. Only the model based on the mean CE2 proves a good correlation $R^{2}=0.8118$ with trend line lying close to ideal.

\section{Underestimation and overestimation of blood volume to process}

An algorithm can underpredict the target dose, which means that the predicted dose will be lower than actual. It can also overpredict the dose; therefore, the predicted dose will be higher than the collected one. Overprediction also means that the algorithm underestimates blood volume to process. This may result in the repetition of apheresis or even mobilization failure. We enumerated the number of underestimations and overestimations of blood volume to process to study the safety of each prediction model (Figure 5).

MNC models again showed consistent results with slightly more underestimations than overestimations (Figure $5 \mathrm{~A}-\mathrm{C}$ ). . cMNC regression models underestimated blood volume to process in most cases (Figure $5 \mathrm{E}, \mathrm{F}$ ). Only the mean CE2 model gave a similar number of underestimations and overestimations (Figure 5D). 


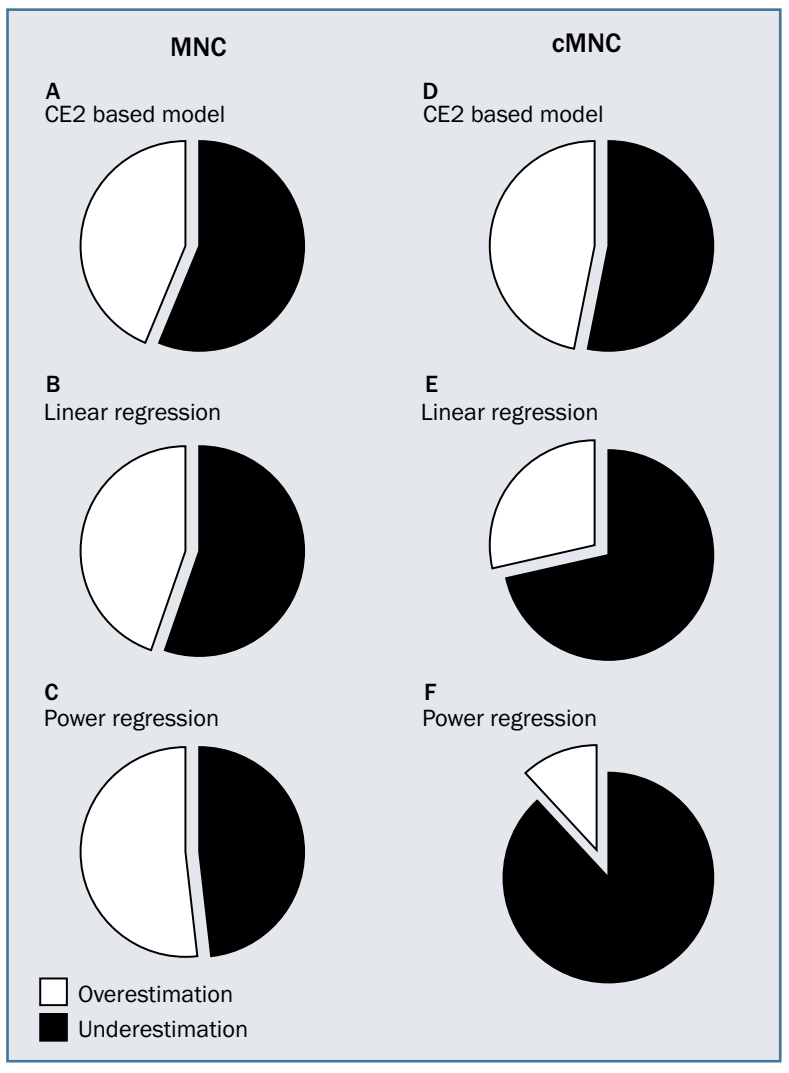

Figure 5A-F. The white color represents the number of procedures that overestimated blood volume to process and the gray color represents underestimation. The latter situation is particularly dangerous because of the need for apheresis repetition and mobilization failure risk; MNC - mononuclear cell collection; cMNC - continuous mononuclear cell collection

\section{Discussion}

\section{MNC versus cMNC}

\section{Safety and performance}

The relative safety and simplicity of peripheral stem cell collection rendered blood separators widely utilized in hematopoietic stem cell transplantation. Although severe adverse events happen rarely [20], professionals constantly pay attention to the safety of a procedure, particularly when introducing a new apheresis protocol [12]. Although some data about the new cMNC protocol have been published $[11,15,21]$, we have carefully examined patient blood parameters to ensure safety.

The anticoagulant consumption did not differ, which made the new procedure as safe as the MNC in terms of anticoagulation optimization. This is not surprising as the device manages anticoagulation identically, and settings for both protocols are managed equally.

Hemoglobin and platelet count are often below the reference level in mobilized patients after chemotherapy treatment. Shlenke et al. [22] considered hemoglobin (Hg) level above $9 \mathrm{~g} / \mathrm{dL}$ safe and platelet level above $30 \times 10^{9} / \mathrm{L}$ satisfactory for performing a safe apheresis. By selecting a proper Spectra Optia parameter setup and the appropriate collection set, transfusion can be avoided. The MNC protocol will be suited for patients with critically low hemoglobin levels, and the cMNC protocol will be beneficial in individuals with critically low platelet count. This is a very important conclusion that illustrates how understanding of apheresis principles impacts the planning of collection procedures.

The occurrence of adverse events after the infusion of PBSC is related to the number of granulocytes in the graft. It is stressed that high-quality apheresis product is needed for transplantation [23]. As the granulocyte content between two protocols did not differ, we conclude that the new protocol again fulfills acceptance criteria and is safe.

The mean CE2 value of $56.0 \%$ for MNC and $47.6 \%$ for the CMNC protocol correspond to the published ones [11, $12,15,17,21,24,25]$. The consistency of Spectra Optia performance results, revealed by different authors, supports repeatability of devices. Consequently, our findings may have a relevant impact on the work of apheresis units, which utilize prediction algorithms to calculate blood volume to process.

\section{Accuracy of prediction models}

A reliable algorithm for determining blood volume to process should enable us to collect enough cells for a transplantation and prevent unnecessary long procedures. Prediction models for MNC procedures were comparable and suggest high reproducibility of the procedure. Performance variables support this conclusion as they are similar to those published by other authors $[12,15,17,21,24-26]$.

The most significant differences between the algorithms were observed in the cMNC protocol. Which model should be therefore utilized for clinical practice? Regression models showed either a worse correlation (particularly for $\mathrm{CD} 34^{+}$precount below 100 cells/ $\mu \mathrm{L}$ ) or significant overprediction. The regression models are based on an entire range of $\mathrm{CD}_{3} 4^{+}$precounts. If the correlation is not ideally linear, high values can increase discrepancy. This observation is consistent with observations made by other authors who note that $\mathrm{CD} 34^{+}$precount $>200$ cells $/ \mu \mathrm{L}$ is considered as an outlier [27]. This data, coming from patients called super mobilizers, affected the model, resulting in overprediction. This can be especially dangerous for poor mobilizers when underestimation of blood volume to process can increase probability of mobilization failure.

In contrast to the MNC protocol, where all models were accurate, for the CMNC, only the mean CE2-based model was proven to be reliable. It contributed to a good correlation during the validation and did not show overestimation or underestimation. 


\section{Which algorithm to choose?}

The authors have considered the regression model a good tool for determining blood volume to process. However, they have also reported that the prediction algorithm was not followed unreservedly as there was a risk of collecting an insufficient number of $\mathrm{CD} 34^{+}$cells [17]. This approach did not enable to reveal the number of undercollections, but it was reasonable in terms of patient safety. The CE2-based model, applied and validated in the MNC protocol, did not differ from the regression models. When the model was applied in the cMNC protocol, the most accurate results were obtained.Hence, we suggest utilization of this model for clinical practice.

As was said in the introduction, many models and approaches have been presented and examined, but there is no publication which would compare these models. Further studies in the field of prediction models are required. Despite limitations of retrospective studies, this analysis has provided a safe way to notice hazardous inaccuracy of regression models. With a low $\mathrm{CD} 34^{+}$precount, the calculated blood volume to process differed fivefold between models. The CE2-based model is simple, but yet no one has developed a model which would significantly change prediction accuracy. Although WBC precount also correlates with $\mathrm{CD} 34^{+}$yield, it does not increase multiple regression model (data not shown).

In conclusion, the CE2 model is a simple method, yet reliable for all $\mathrm{CD} 34^{+}$precounts. Moreover, it can be easily adjusted by constrained CE2 decrease to avoid undercollections. The utility and simplicity of this method should promote accurate planning of apheresis and procedure parameters among apheresis unit operators, which will improve patients' safety.

\section{Authors' contributions}

RM - conception and design of the work, acquisition, analysis, interpretation of data for the work, preparation of the manuscript, final approval of the version to be published; $\mathrm{OG}, \mathrm{AS}, \mathrm{AP}, \mathrm{MC}, \mathrm{PS}$ - substantial contribution to the drafting and editing of the manuscript; KB, MN, KZ - acquisition, analysis of technical data for the work, revising the work critically for statistical analysis; AW - revising the work critically for important intellectual content, final approval of the version to be published.

\section{Acknowledgments}

The authors would like to thank Maria Kasprzak for providing language help.

\section{Conflict of interest}

None.

\section{Financial support}

The authors received no specific funding for this work.

\section{Ethics}

The work described in this article has been carried out in accordance with The Code of Ethics of the World Medical Association (Declaration of Helsinki) for experiments involving humans; EU Directive 2010/63/EU for animal experiments; Uniform requirements for manuscripts submitted to biomedical journals.

\section{References}

1. Morgan G. Optimising strategies for the Spectra Optia. Transfus Apher Sci. 2013; 49(3): 688-691, doi: 10.1016/j.transci.2013.09.011, indexed in Pubmed: 24269748.

2. Pusic I, Jiang SY, Landua S, et al. Impact of mobilization and remobilization strategies on achieving sufficient stem cell yields for autologous transplantation. Biol Blood Marrow Transplant. 2008; 14(9): 1045-1056, doi: 10.1016/j.bbmt.2008.07.004, indexed in Pubmed: 18721768.

3. Ford CD, Chan KJ, Reilly WF, et al. An evaluation of predictive factors for CD34+ cell harvest yields from patients mobilized with chemotherapy and growth factors. Transfusion. 2003; 43(5): 622-625, doi: 10.1046/j.1537-2995.2003.00376.x, indexed in Pubmed: 12702184.

4. Hequet 0 . Hematopoietic stem and progenitor cell harvesting: technical advances and clinical utility. J Blood Med. 2015; 6: 55-67, doi: 10.2147/JBM.S52783, indexed in Pubmed: 25733943.

5. Moog R, Moog R, Uppenkamp M, et al. Technical aspects and performance in collecting peripheral blood progenitor cells. Ann Hematol. 1998; 77(4): 143-147, doi: 10.1007/s002770050431, indexed in Pubmed: 9829844.

6. Armitage S, Hargreaves R, Samson D, et al. CD34 counts to predict the adequate collection of peripheral blood progenitor cells. Bone Marrow Transplant. 1997; 20(7): 587-591, doi: 10.1038/sj.bmt.1700938, indexed in Pubmed: 9337061.

7. Chen JP, Burns K, Kennedy M, et al. A method to predict the yield of peripheral blood stem cells collected by large volume leukapheresis. J Blood Lymph. 2017; 7(1), doi: 10.4172/2165-7831.1000160.

8. Mohty M, Hübel K, Kröger N, et al. Autologous haematopoietic stem cell mobilisation in multiple myeloma and lymphoma patients: a position statement from the European Group for Blood and Marrow Transplantation. Bone Marrow Transplant. 2014; 49(7): 865-872, doi: 10.1038/bmt.2014.39, indexed in Pubmed: 24686988.

9. Trickett AE, Smith S, Kwan YL. Accurate calculation of blood volume to be processed by apheresis to achieve target CD34+ cell numbers for PBPC transplantation. Cytotherapy. 2001; 3(1): 5-10, doi: 10.1080/146532401753156359, indexed in Pubmed: 12028838.

10. Pierelli L, Maresca M, Piccirillo N, et al. Accurate prediction of autologous stem cell apheresis yields using a double variable-dependent method assures systematic efficiency control of continuous flow collection procedures. Vox Sang. 2006; 91(2): 126-134, doi: 10.1111/j.1423-0410.2006.00796.x, indexed in Pubmed: 16907873.

11. Pandey S, Cottler-Fox M. Optia ${ }^{\circledR}$ continuous mononuclear collection (CMNC) system is a safe and efficient system for hematopoietic progenitor cells-apheresis (HPC-a) collection and yields a lower product hematocrit (HCT\%) than the $\mathrm{COBE}^{\oplus}$ spectra system: a retrospective study. J Clin Apher. 2018; 33(4): 505-513, doi: 10.1002/jca.21629, indexed in Pubmed: 29603795. 
12. Cousins AF, Sinclair JE, Alcorn MJ, et al. HPC-A dose prediction on the optia $\circledast$ cell separator based on a benchmark CE2 collection efficiency: Promoting clinical efficiency, minimizing toxicity, and allowing quality control. J Clin Apher. 2015; 30(6): 321-328, doi: 10.1002/jca.21380, indexed in Pubmed: 25619791.

13. Douglas K, McGarvey M, Robertson S, et al. "Will I have enough cells for a transplant, doctor?" Validation of a $\mathrm{CD} 34+$ dose prediction formula using patient weight, peripheral CD34+ count and predicted end-run results in a series of 440 consecutive PBSC collection procedures using the MNC program on COBE Spectra. (Abstract). J Clin Apheresis. 2008; 23: 21-2.

14. Rosenbaum ER, O'Connell $B$, Cottler-Fox M. Validation of a formula for predicting daily $\mathrm{CD} 34(+)$ cell collection by leukapheresis. Cytotherapy. 2012; 14(4): 461-466, doi: 10.3109/14653249.2011.652733, indexed in Pubmed: 22277012.

15. Lisenko K, Pavel P, Bruckner T, et al. Comparison between intermittent and continuous spectra optia leukapheresis systems for autologous peripheral blood stem cell collection. J Clin Apher. 2017; 32(1): 27-34, doi: 10.1002/jca.21463, indexed in Pubmed: 27095367.

16. Mitterer M, Hirber J, Gentilini I, et al. Target value tailored (TVT) apheresis approach for blood progenitor cell collection after high-dose chemotherapy and rh-G-CSF. Bone Marrow Transplant. 1996; 18(3): 611-617, indexed in Pubmed: 8879626.

17. Leberfinger DL, Badman KL, Roig JM, et al. Improved planning of leukapheresis endpoint with customized prediction algorithm: minimizing collection days, volume of blood processed, procedure time, and citrate toxicity. Transfusion. 2017; 57(3): 685-693, doi: 10.1111/ /trf.13925, indexed in Pubmed: 28019012.

18. Sheppard D, Tay J, Palmer D, et al. Improved prediction of CD34+ cell yield before peripheral blood hematopoietic progenitor cell collection using a modified target value-tailored approach. Biol Blood Marrow Transplant. 2016; 22(4): 763-767, doi: 10.1016/j. bbmt.2015.11.016, indexed in Pubmed: 26643030.

19. Reinhardt $P$, Brauninger $S$, Bialleck $H$, et al. Automatic interface-controlled apheresis collection of stem/progenitor cells: results from an autologous donor validation trial of a novel stem cell apheresis device. Transfusion. 2011; 51(6): 1321-1330, doi: 10.1111/j.1537-2995.2010.02992.x, indexed in Pubmed: 21155834.

20. Moog R. Adverse events in peripheral progenitor cell collection: a 7-year experience. J Hematother Stem Cell Res. 2001; 10(5): 675-680, doi: 10.1089/152581601753193896, indexed in Pubmed: 11672514.

21. Sanderson F, Poullin P, Smith R, et al. Peripheral blood stem cells collection on spectra optia apheresis system using the continuous mononuclear cell collection protocol: A single center report of 39 procedures. J Clin Apher. 2017; 32(3): 182-190, doi: 10.1002/jca.21485, indexed in Pubmed: 27442837.

22. Schlenke P, Frohn C, Steinhardt MM, et al. Clinically relevant hypokalaemia, hypocalcaemia, and loss of hemoglobin and platelets during stem cell apheresis. J Clin Apher. 2000; 15(4): 230-235, doi: 10.1002/1098-1101(2000)15:4<230::aid-jca3>3.0.co;2-b, indexed in Pubmed: 11124690.

23. Cordoba R, Arrieta R, Kerguelen A, et al. The occurrence of adverse events during the infusion of autologous peripheral blood stem cells is related to the number of granulocytes in the leukapheresis product. Bone Marrow Transplant. 2007; 40(11): 1063-1067, doi: 10.1038/ /sj.bmt.1705861, indexed in Pubmed: 17906706.

24. Accorsi P, Passeri C, lacone A. A multiple regression analysis on factors influencing haematopoietic progenitor cell collection for autologous transplantation. Transfus Apher Sci. 2012; 47(2): 223-227, doi: 10.1016/j.transci.2012.06.009, indexed in Pubmed: 22824508.

25. Besson N, Topholm Bruun M, Stauffer Larsen T, et al. Impact of apheresis automation on procedure quality and predictability of CD34 cell yield. J Clin Apher. 2018; 33(4): 494-504, doi: 10.1002/jca.21625, indexed in Pubmed: 29570217.

26. Spoerl S, Wäscher D, Nagel S, et al. Evaluation of the new continuous mononuclear cell collection protocol versus an older version on two different apheresis machines. Transfusion. 2018; 58(7): 1772-1780, doi: 10.1111/trf.14644, indexed in Pubmed: 29732573.

27. Chepovetsky J, Yoon SC, Blouin AG, et al. Roles of peripheral blood $\mathrm{CD} 34+$ cell count and midpoint collection CD34+ cell yield for peripheral blood stem cell collections from autologous patients mobilized by G-CSF and plerixafor. NAJ Med Sci. 2013; 6(2): 63-70. 